\title{
Lessons from the Sandbox: Is Unexplained Nitrogen Real?
}

\author{
Bernard T. Bormann, ${ }^{1 *}$ C. Kent Keller, ${ }^{2}$ Deane Wang, ${ }^{3}$ and \\ F. Herbert Bormann ${ }^{4}$
}

\begin{abstract}
${ }^{1}$ USDA Forest Service Research, 3200 S.W. Jefferson Way, Corvallis, Oregon 97331, USA; ${ }^{2}$ Department of Geology, Washington State University, 1228 Webster Physical Sciences Building, Pullman, Washington 99164-2812, USA; ${ }^{3}$ School of Natural Resources, University of Vermont, 323 Aiken Center, Burlington, Vermont 05405, USA; ${ }^{4}$ School of Forestry and Environmental Studies, Yale University, 205 Prospect Street, New Haven, Connecticut 06511, USA
\end{abstract}

\begin{abstract}
In their review of 24 studies of forest nitrogen $(\mathrm{N})$ budgets, Binkley and others (2000) found that only one of them supported the conclusion that an $\mathrm{N}$ accumulation of more than $25 \mathrm{~kg} \mathrm{~N} \mathrm{ha}^{-1} \mathrm{y}^{-1}$ is possible without known symbiotic $\mathrm{N}_{2}$-fixing plants. They contended that, given how well the $\mathrm{N}$ cycle is known, new $\mathrm{N}$ accumulation pathways are unlikely. They also concluded that the Hubbard Brook sandbox study (Bormann and others 1993) was insufficiently replicated and had low precision in vegetation and soil estimates. Here we reevaluate and extend the sandbox analysis and place the findings in a broader context. Using multiple methods of estimating vegetation $\mathrm{N}$ accumulation in pine sandboxes, we arrived at results that differed from the reported rates but still strongly supported large biomass $\mathrm{N}$ accumulation. The original study's conclusions about soil $\mathrm{N}$ changes were strengthened when new evidence showed that $\mathrm{N}$ accumulated in
\end{abstract}

lower horizons and that the sandboxes were successfully homogenized at the beginning of the experiment. Unexplained ecosystem $\mathrm{N}$ accumulation ranged from about 40 to $150 \mathrm{~kg} \mathrm{ha}^{-1} \mathrm{y}^{-1}$, with $95 \%$ confidence intervals that did not include zero. No evidence was found that could balance the sandbox ecosystem $\mathrm{N}$ budgets without adding unexplained N. Unreplicated experiments, such as the sandboxes, can explore the possibility that $\mathrm{N}$ can accumulate in ways not explainable by mass balance analysis, but they cannot quantify the frequency and extent of the phenomenon. New studies should combine substantive microbiological, mass balance, and process research using multiple direct measures of $\mathrm{N}_{2}$ fixation.

Key words: unexplained nitrogen accumulation; lysimeters; mesocosms; ecosystem budgets; mass balance; nitrogen fixation.

\section{INTRODUCTION}

A vigorous debate has emerged about whether nitrogen $(\mathrm{N})$ can accumulate at rapid rates (exceeding $25 \mathrm{~kg} \mathrm{ha}^{-1} \mathrm{y}^{-1}$ ) in ecosystems without known symbiotic $\mathrm{N}_{2}$ fixers. The evidence for such rapid accumulation comes from studies of grass ecosystems lacking known symbiotic $\mathrm{N}_{2}$ fixers, including those

Received 4 September 2001; accepted 3 April 2002.

*Corresponding author; e-mail: bbormann@fs.fed.us. by Whitt (1941), Chapman and others (1949), Karraker and others (1950), Smith and others (1954), App and others (1980), Lima and others (1987), and Cavalcante and Dobereiner (1988). The rapid accumulation of $\mathrm{N}$ has been reported in forest ecosystems as well (Dickson and Crocker 1953; Fisher and Eastburn 1974; Day and others 1975; Jenny 1980; Turvey and Smethurst 1988; Son and Gower 1992; Bormann and others 1993; Eriksson and Rosen 1994; Johnson and Todd 1998).

In a recent review of many of the forest studies, 
Binkley and others (2000) concluded that there is "no widespread evidence of high rates of occult [unexplained] $\mathrm{N}$ input in forests." This conclusion appears to be based on their assessment of the experimental designs, the size of the experimental errors, the measures of inputs or outputs, and a belief that "the $\mathrm{N}$ cycle of forest ecosystems is understood relatively well." We agree that skepticism is appropriate; however, skepticism should not lead to dismissal based on conventional wisdom.

Small-scale experimental mesocosm studies have a number of advantages over field experiments because they can control treatment effects, limit errors, and allow the measures needed for more complete mass balance analyses. The Hubbard Brook sandbox experiment was designed as a mesocosm study to examine whether pioneer plants that appear to grow well in $\mathrm{N}$-poor environments but are not known to be symbiotic $\mathrm{N}_{2}$ fixers, are somehow associated with unexplained $\mathrm{N}$ accumulations on an ecosystem basis. The researchers concluded that the evidence for an unexplained net $\mathrm{N}$ accumulation-of $50 \mathrm{~kg} \mathrm{ha}^{-1} \mathrm{y}^{-1}$ or more-was strong in two pine ecosystems (Bormann and others 1993).

How, then, did the Binkley review conclude that high error and poor design did not yield high confidence for rapid $\mathrm{N}$ accumulation in the sandbox study? In this paper, we analyze these conflicting conclusions by reevaluating the original data, examining sources of uncertainty in greater detail, and presenting previously unreported data. Alternative methods of estimating unexplained $\mathrm{N}$ are compared, and new results are placed in the context of our understanding of the $\mathrm{N}$ cycle.

\section{BACKGROUND AND METHODS}

The sandbox study was initiated in 1982 as an adaptation of the small-watershed approach to nutrient cycling, as applied to the cycling of $\mathrm{N}$ in experimental ecosystems (Bormann and others 1987). The study is described in detail in Bormann and others (1993) and summarized briefly by Binkley and others (2000).

Sandbox ecosystems were built in two sizes, $2.5 \times 2.5 \mathrm{~m}$ wide and $7.5 \times 7.5 \mathrm{~m}$ wide by $1.5 \mathrm{~m}$ deep, lined with Hypalon polymer landfill liner, and filled with screened, homogenized, low-N fluvial outwash sand from a glacial deposit in central New Hampshire. Various species were planted, each in its own box, including two pines-red (Pinus resinosa Ait.) and pitch (Pinus rigida Mill.) -European black alder (Alnus glutinosa (L.) Gaertn.), and black locust (Robinia pseudoacacia L.). In addition, a control "no veg" box was built in which vascular plants were not allowed to grow. Outside buffers (three or six rows of seedlings) were planted to create uniform stand conditions by reducing edge effects inside the boxes. The sandboxes were allowed to settle for a year, and initial $\left(\mathrm{t}_{0}\right)$ soil samples were taken 1 year after planting, before the seedlings began to grow rapidly.

In an ecosystem without significant $\mathrm{N}_{2}$ fixation, dry deposition, or denitrification, $\mathrm{N}$ accumulation in vegetation $\left(\Delta \mathrm{N}_{\mathrm{veg}}\right)$ and soil $\left(\Delta \mathrm{N}_{\mathrm{soil}}\right)$ is limited to net meteoric input - that is, input in bulk precipitation $\left(\mathrm{N}_{\mathrm{bp}}\right)$ less loss in drainage $\left(\mathrm{N}_{\mathrm{dr}}\right)$ :

$$
\mathrm{N}_{\mathrm{bp}}-\mathrm{N}_{\mathrm{dr}}=\Delta \mathrm{N}_{\mathrm{veg}}+\Delta \mathrm{N}_{\text {soil }}
$$

If the accumulation cannot be explained by net meteoric input, a term $\left(\mathrm{N}_{\text {unexplained }}\right)$ must be added to the lefthand side of the equation:

$$
\mathrm{N}_{\mathrm{bp}}-\mathrm{N}_{\mathrm{dr}}+\mathrm{N}_{\text {unexplained }}=\Delta \mathrm{N}_{\mathrm{veg}}+\Delta \mathrm{N}_{\text {soil }}
$$

which can be rearranged to give:

$$
\mathrm{N}_{\text {unexplained }}=\Delta \mathrm{N}_{\mathrm{veg}}+\Delta \mathrm{N}_{\mathrm{soil}}-\mathrm{N}_{\mathrm{bp}}+\mathrm{N}_{\mathrm{dr}}
$$

The terms on the right side of Eq. (1) were evaluated by using standard analytical techniques (Bormann and others 1993) for samples representing conditions at $t_{0}$ and for samples collected 4 to 5 years later, representing final "5-year" conditions. Initial soil samples were collected using a cylindrical 5.3-cm-diameter soil corer. Because of the corer's poor performance when roots were present, a steel box sampler was used for the final sampling of all soil under the growing space (the $0.5 \times 0.5 \mathrm{~m}$ area under a sampled tree). Change in vegetation $\mathrm{N}$ was estimated as the sum of final root, litter, and aboveground biomass $\mathrm{N}$-based on the sampling and processing of entire trees-less seedling N. An alternative method was also used to estimate $\mathrm{N}$ accumulation in vegetation aboveground: regressing $\mathrm{N}$ mass $\left(\mathrm{kg} \mathrm{ha}^{-1}\right)$ on tree heights of sampled trees and extending the predictions to a sandbox with heights measured on all trees. Standard methods (Cochran 1977) were used to estimate a mean and confidence interval based on the regression. Rarely, a few small-diameter or missing trees resulted in a negative estimate of $\mathrm{N}$ mass; these were set to zero. We did not measure denitrification or dust inputs and assume these fluxes to be very small. The three- to six-tree outside buffers reduced dust inputs, and we saw little indication of extraneous litter.

We used an approximate formula for estimating confidence intervals for the sums of components added to calculate ecosystem unexplained $\mathrm{N}$ values, 
Table 1. Original Estimates (Bormann and others 1993) and 95\% Confidence Intervals for Components ${ }^{a}$ of Unexplained Nitrogen (N) Accumulation or Loss Estimated by Mass Balance

\begin{tabular}{|c|c|c|c|c|c|}
\hline Sandbox & $\begin{array}{l}\Delta \mathrm{N}_{\text {veg }} \\
\left(\mathrm{kg} \mathrm{N}_{\mathrm{ha}}^{-1} \mathrm{y}^{-1}\right)\end{array}$ & $\begin{array}{l}\Delta \mathrm{N}_{\text {soil }}(\mathrm{0-20}) \\
\left(\mathrm{kg} \mathrm{N} \mathrm{ha}^{-1} \mathrm{y}^{-1}\right)\end{array}$ & $\begin{array}{l}\mathrm{N}_{\mathrm{bp}} \\
\left(\mathrm{kg} \mathrm{N} \mathrm{ha} \mathrm{N}^{-1} \mathrm{y}^{-1}\right)\end{array}$ & $\begin{array}{l}\mathrm{N}_{\mathrm{dr}} \\
\left(\mathrm{kg} \mathrm{N} \mathrm{ha} \mathrm{N}^{-1} \mathrm{y}^{-1}\right)\end{array}$ & $\begin{array}{l}\mathrm{N}_{\text {unexplained }} \\
\left(\mathrm{kg} \mathrm{N} \mathrm{ha}^{-1} \mathrm{y}^{-1}\right)\end{array}$ \\
\hline Alder & $175 \pm 12$ & $86 \pm 52$ & 5 & $1^{b}$ & $255 \pm 56$ \\
\hline Locust & $52 \pm 18$ & $43 \pm 60$ & 5 & $1^{b}$ & $90 \pm 70$ \\
\hline Red pine & $83 \pm 8$ & $-17 \pm 23$ & 5 & 1 & $62 \pm 34$ \\
\hline Pitch pine & $70 \pm 40$ & $-19 \pm 25$ & 5 & $1^{b}$ & $49 \pm 47$ \\
\hline No veg & 0 & $-96 \pm 77$ & 5 & 7 & $-94 \pm 75$ \\
\hline
\end{tabular}

${ }^{a}$ Components: $\Delta N_{\text {veg }}$ and $\Delta N_{\text {soil(o-20) }}$ are changes in storage in vegetation and upper soil, $N_{b p}$ is input in bulk precipitation, $N_{d r}$ is loss in drainage, and $N_{\text {unexplained }}$ is the net unexplained $N$ needed to balance the equation $\left(N_{\text {unexplained }}=\Delta N_{\text {veg }}+\Delta N_{\text {soil }(0-20)}-N_{b p}+N_{d r}\right)$.

${ }^{b}$ Drainage for alder, locust, and pitch pine was based on the estimate from a red pine sandbox.

following Bormann and others (1993). This formula takes the square root of the sum of the squared $95 \%$ half-intervals for vegetation and soil $\mathrm{N}$ values (Meyer 1975). Interval estimates for sums have two possible complications: They assume no covariance (which could increase or decrease the intervals), and they do not account for unequal sample sizes (L. Ganio personal communication). The data suggest that there is little correlation between aboveground vegetation and soil $\mathrm{N}$ estimates, likely because the roots extend far beyond the $0.5 \times 0.5 \mathrm{~m}$ space sampled beneath each tree.

The results of the mass balances, as reported in 1993, are summarized in Table 1. For reasons discussed below, accumulation in soil was based only on analyses of the upper $20 \mathrm{~cm}$. Our reassessment of the sandbox data centered on checking the original calculations, reevaluating sources of uncertainty, devising ways to lower estimates of accumulations, and reevaluating the scope of our inferences. By these means, we tried to find, in the same spirit of skeptical assessment expressed by Binkley and others (2000), any reasonable grounds to overturn our original conclusions.

\section{RESULTS}

Binkley and others (2000) focused on vegetation and soil $\mathrm{N}$ pools in the red pine and pitch pine ecosystems. Our reexamination has a parallel focus.

\section{$\mathrm{N}$ in Vegetation}

Binkley and others (2000) noted that there were large, within-plot confidence intervals associated with the 1993 estimates of aboveground pine biomass. On rechecking, we found an error in the 1993 confidence intervals for aboveground biomass and litter, which were shown with $99 \%$ intervals, not
$95 \%$ intervals as stated in the text. The actual means and $95 \%$ intervals for 5 -year aboveground $\mathrm{N}$ accumulation are $63 \pm 34 \mathrm{~kg} \mathrm{ha}^{-1} \mathrm{y}^{-1}$ in red pine and $45 \pm 21 \mathrm{~kg} \mathrm{ha}^{-1} \mathrm{y}^{-1}$ in pitch pine (Table 2). This error was not found in any of the other mass balance components reported, and it was not carried to the 1993 calculation of intervals for ecosystem $\mathrm{N}$ accumulation.

Binkley and others (2000) also expressed concern about the sample size, especially for the small red pine and alder sandboxes containing 16 trees planted at a 0.5 -m spacing inside of three outsidebuffer rows. We evaluated the effect of tree position on height in the small red pine and alder sandboxes. The 12 inside-box buffer trees in the red pine sandbox were $14 \%$ shorter than the central four trees but were not significantly different $(P=0.31)$; the opposite pattern was observed in the alder sandbox, where the central four trees were $10 \%$ shorter than the 12 inside-box buffer trees but not significantly so $(P=0.24)$.

We sought an alternative estimate of aboveground red pine biomass $\mathrm{N}$ based on a regression of aboveground $\mathrm{N}$ mass $\left(\mathrm{kg} \mathrm{ha}^{-1}\right)$ on height $(\mathrm{cm})$ of sampled red pine trees:

$$
\text { Aboveground red pine } \begin{aligned}
\mathrm{N} & =-383.1 \\
& +4.448 \cdot \text { height }
\end{aligned}
$$

We used this method to calculate $\mathrm{N}$ in all interior trees. The regression produces an estimate and 95\% confidence interval for aboveground $\mathrm{N}$ accumulation of $55 \pm 22 \mathrm{~kg} \mathrm{~N} \mathrm{ha}^{-1} \mathrm{y}^{-1}$, which differs from the original estimate of $63 \pm 34 \mathrm{~kg} \mathrm{~N} \mathrm{ha}^{-1} \mathrm{y}^{-1}$ (Table 2). A single dead tree in the buffer contributed strongly to the lower estimate of the regression-based mean. The confidence interval is smaller, even though the slope coefficient is not 
Table 2. Original and Revised Estimates of Annual N Change and 95\% Confidence Intervals for Aboveground Vegetation and Soil in Pine Sandboxes ${ }^{a}$

\begin{tabular}{|c|c|c|c|c|}
\hline \multirow[b]{2}{*}{$\begin{array}{l}\text { Mass Balance } \\
\text { Components }\end{array}$} & \multicolumn{2}{|c|}{ Red Pine } & \multicolumn{2}{|c|}{ Pitch Pine } \\
\hline & $\begin{array}{l}1993 \text { Study }^{b} \\
\left(\mathrm{~kg} \mathrm{~N} \mathrm{ha}^{-1} \mathrm{y}^{-1}\right)\end{array}$ & $\begin{array}{l}\text { This Study } \\
\left(\mathrm{kg} \mathrm{N} \mathrm{ha}^{-1} \mathrm{y}^{-1}\right)\end{array}$ & $\begin{array}{l}1993 \text { Study }^{b} \\
\left(\mathrm{~kg} \mathrm{~N} \mathrm{ha}^{-1} \mathrm{y}^{-1}\right)\end{array}$ & $\begin{array}{l}\text { This Study } \\
\left(\mathrm{kg} \mathrm{N} \mathrm{ha}^{-1} \mathrm{y}^{-1}\right)\end{array}$ \\
\hline$\Delta \mathrm{N}_{\text {veg }}$ aboveground $^{c}$ & $63 \pm 34$ & & $45 \pm 21$ & \\
\hline Regression mean & & $55 \pm 22$ & & $36 \pm 7$ \\
\hline Weighted mean & & & & $44 \pm 22$ \\
\hline Unweighted mean & & & & $45 \pm 21$ \\
\hline NonADJ trees mean ${ }^{d}$ & & & & $42 \pm 22$ \\
\hline \multicolumn{5}{|l|}{$\Delta \mathrm{N}_{\text {soil }} e^{e}$} \\
\hline Upper $(0-20 \mathrm{~cm})$ & $-17 \pm 23$ & $-28 \pm 18$ & $-19 \pm 25$ & $-9 \pm 13$ \\
\hline Lower (20-135 cm) & 0 & $98 \pm 11$ & 0 & $73 \pm 9$ \\
\hline Total soil & $-17 \pm 23$ & $70 \pm 21$ & $-19 \pm 25$ & $64 \pm 16$ \\
\hline \multicolumn{5}{|c|}{$\begin{array}{l}\text { a Annual rates can be multiplied by } 5.2 \text { years for red pine and } 5.3 \text { years for pitch pine vegetation and } 3.9 \text { years for soils to obtain } N \text { changes between the beginning and end } \\
\text { of the experiment. } \\
{ }^{b} \text { From Bormann and others (1993). } \\
{ }^{c} \text { These values do not include belowground biomass and litter as in Table } 1 \text {. } \\
{ }^{d} \text { NonADJ trees are trees not adjacent to hybrid or missing-tree cells. } \\
{ }^{\circ} \text { Upper-and lower-soil changes are shown and compared to other sandboxes in Figures } 1 \text { and } 2 .\end{array}$} \\
\hline
\end{tabular}

significant $\left(r^{2}=0.33\right.$, s.e. $\beta_{0}=386$, s.e. $\beta_{1}=2.39$, $n=6, P=0.14)$.

For the large pitch pine sandbox, alternative estimates for aboveground $\mathrm{N}$ accumulation are motivated by an accidentally introduced source of uncertainty. Seedling mortality in the 1st year, and accidental replanting with pitch loblolly hybrids, led Bormann and others (1993) to divide the population into three groups with various numbers of individuals $(n)$ : cells with younger trees, planted where hybrids were removed (two); cells with trees adjacent to hybrid cells, which may have benefited from more growing space (nine); and cells with trees not adjacent to hybrid cells (37). Initially reported aboveground $\mathrm{N}$ mass (Table 2 ) was based on weighted averages for trees randomly selected from the adjacent and nonadjacent populations.

We sought an alternative estimate of aboveground pitch pine biomass $\mathrm{N}$ based on a regression of aboveground $\mathrm{N}$ mass $\left(\mathrm{kg} \mathrm{ha}^{-1}\right)$ on height $(\mathrm{cm})$ of sampled pitch pine trees:

$$
\text { Aboveground pitch pine } \begin{aligned}
\mathrm{N} & =-624.5 \\
& + \text { height } \cdot 5.195
\end{aligned}
$$

We then extended it to all trees in the population of 84 cells $\left(r^{2}=0.91\right.$, s.e. $\beta_{0}=88$; s.e. $\beta_{1}=0.50 ; n=$ $12, P<0.001)$. The regression approach reduces the estimate of average $\mathrm{N}$ accumulation in pitch pine aboveground from $45 \pm 21$ to $36 \pm 7 \mathrm{~kg} \mathrm{ha}^{-1}$ $\mathrm{y}^{-1}$ (Table 2).
Further, we investigated alternative approaches to the pitch pine, hybrid neighbor problem. One approach allocated the growing space of each missing or hybrid cell to the four adjacent trees and weight samples on areas of nonadjacent and adjacent plus hybrid cells before calculating $\mathrm{N}$ accumulation. With this method, adjacent and nonadjacent tree means are more similar than they were in the original estimates (differences are less significant at $P=0.57$ ), producing a mean and $95 \%$ confidence interval of $44 \pm 22 \mathrm{~kg} \mathrm{~N} \mathrm{ha}^{-1}$. When all values from adjacent trees are disregarded, we obtained $42 \pm 22$ $\mathrm{kg} \mathrm{N}$ ha ${ }^{-1}$; when means from all samples are not weighted at all, we obtained $45 \pm 21 \mathrm{~kg} \mathrm{~N} \mathrm{ha}^{-1}$ (Table 2). All of these estimates support the conclusion that pitch pine has a large, significant aboveground $\mathrm{N}$ accumulation of a magnitude similar to that of red pine.

\section{$\mathrm{N}$ in Soil}

Binkley and others (2000) questioned the assumption that the initial soil conditions were similar among the sandboxes and further asked whether this and some additional uncertainty in the final soil $\mathrm{N}$ estimates might mask a large depletion of soil $\mathrm{N}$ translocated into aboveground biomass. Here we evaluate these two sources of uncertainty.

The first uncertainty concerns the 1993 assumption of initial interbox similarity of the $\mathrm{N}$ masses in the deep $(20-135 \mathrm{~cm})$ soil. Lower soil was sampled at $t_{0}$ only in the nonvegetated box. Because the boxes 
contained intensively homogenized soils, repeating the difficult deep sampling on other boxes was deemed to be unnecessary. Additional analysis shows that differences in the percentage of $\mathrm{N}$ in lower-soil samples from the nonvegetated box and composited grab samples-taken from piles after soils were mixed but before they were placed in the other boxes-were small $(2 \%)$ and nonsignificant (two-tailed $t$-test, $P=$ 0.83). Upper soil, which was measured in all boxes at $\mathrm{t}_{0}$, was also similar and not significantly different (ANOVA, $P=0.61$ ). Average tree heights in the three replicate red pine boxes were similar in 1987: 132, 155 , and $155 \mathrm{~cm}$, for an average of $147 \pm 42 \mathrm{~cm}$, which suggests similar initial conditions.

The second uncertainty concerns a possible measurement error associated with changing bulk density measurement techniques. When the bulk densities of 5-year upper $(0-20 \mathrm{~cm})$ soils were compared with soils at $t_{0}$, there were small but significant differences in both red pine and pitch pine-but these differences could have been due to changes in sampling technique, rather than being caused by soil expansion or collapse, as originally assumed (Bormann and others 1993). Here we report an alternative simplified method, where the upper and lower soil masses at 5 years are assumed to also represent the soil masses at $\mathrm{t}_{0}$ and are then multiplied by both the initial and the 5 -year $\mathrm{N}$ concentrations to obtain the initial and 5 -year soil $\mathrm{N}$ masses. The results for upper soils (Figure 1 and Table 2) showed significant (one-tailed $t$-test), large changes in $\mathrm{N}$ mass for the alder $(P<$ $0.001)$ and nonvegetated $(P=0.04)$ treatments but small, nonsignificant $\mathrm{N}$ mass changes for both the red pine $(P=0.14)$ and pitch pine $(P=0.50)$. The large $95 \%$ confidence interval for the nonvegetated box at $\mathrm{t}_{0}$ is influenced by one value. For the lower (20-135 $\mathrm{cm}$ ) soils, highly significant (two-tailed $t$-test, $P<$ 0.001 ) changes in $\mathrm{N}$ concentration and mass were found in the pitch pine, red pine, alder, and nonvegetated boxes (Figure 2 and Table 2). These lower-soil increases for the trees were taken as zero by Bormann and others (1993) because of their limited confidence in initial values; our reanalysis showing small, nonsignificant differences in the initial conditions increases that confidence. In the nonvegetated treatment, the loss of upper-soil $\mathrm{N}$ appears to be nearly balanced by the gain of lower-soil N (Figures 1 and 2). The two pines showed highly significant total soil gains of $70 \pm 21$ and $64 \pm 16 \mathrm{~kg} \mathrm{ha}^{-1}$ (Table 2).

\section{Recalculating N Budgets in the Pine Sandbox Ecosystems}

Methods based on $\mathrm{N}$-height regressions reduced the estimates of the accumulation of total vegetation $\mathrm{N}$ by $7 \%$ to $11 \%$ and decreased uncertainty.

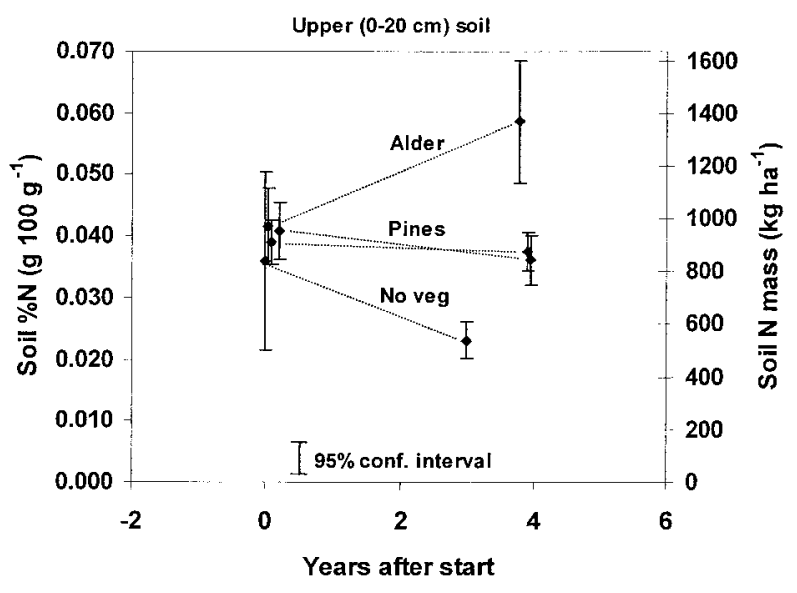

Figure 1. Changes in $\mathrm{N}$ concentration and mass in upper soil layers $(0-20 \mathrm{~cm})$, assuming a fixed soil mass in four sandboxes. Changes were significant with a two-tailed $t$-test in alder $(P=0.01)$ and nonvegetated $(P=0.03)$ boxes and nonsignificant in red pine $(P=0.27)$ and pitch pine $(P=0.57)$ boxes.

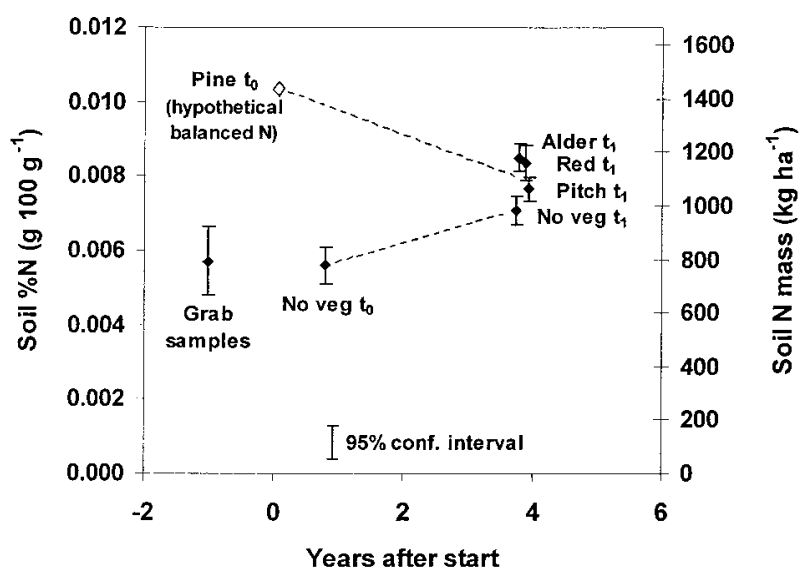

Figure 2. Changes in $\mathrm{N}$ concentration and mass in lower soil layers $(20-135 \mathrm{~cm})$, assuming a fixed soil mass in four sandboxes. Initial nonvegetated lower-soil samples did not differ from composited grab samples taken before boxes were filled $(P=0.83)$. The hypothetical value needed to balance pine vegetation $\mathrm{N}$ gains $(\diamond)$ is nearly double the actual $t_{0}$ values.

Estimated losses of $\mathrm{N}$ from the upper soil by the new fixed-mass method were increased for red pine and decreased for pitch pine. The fixed-mass method, based on strengthened assumptions about the initial conditions, revealed large $\mathrm{N}$ gains for lower soil with small confidence intervals. New estimates for accumulation of $\mathrm{N}$ in the entire sandbox soil $(0-135 \mathrm{~cm})$, based on the fixed-mass method, were also large with small confidence intervals: $70 \pm 21 \mathrm{~kg} \mathrm{ha}^{-1} \mathrm{y}^{-1}$ for red pine and $63 \pm 16 \mathrm{~kg}$ ha ${ }^{-1} \mathrm{y}^{-1}$ for pitch pine. 
Table 3. Revised Calculation ${ }^{a}$ of Unexplained Nitrogen $(\mathrm{N})$-using Alternative Approaches

\begin{tabular}{|c|c|c|c|}
\hline Ecosystem N & Approach $^{b}$ & $\begin{array}{l}\text { Red } \\
\text { Pine }\end{array}$ & $\begin{array}{l}\text { Pitch } \\
\text { Pine }\end{array}$ \\
\hline \multicolumn{4}{|l|}{ Components and sums } \\
\hline Aboveground veg & $\mathrm{N}$-height regression & $54 \pm 22$ & $36 \pm 7$ \\
\hline Roots and litter & 1993 method & $20 \pm 3$ & $29 \pm 5$ \\
\hline$\Delta \mathrm{N}_{\text {veg }}$ total & With regression estimate & $74 \pm 22$ & $65 \pm 9$ \\
\hline$\Delta \mathrm{N}_{\mathrm{veg}}$ total & 1993 method & $83 \pm 8$ & $70 \pm 40$ \\
\hline \multirow{2}{*}{ Upper soil $(0-20 \mathrm{~cm})$} & Fixed-mass (Figure 1) & $-28 \pm 18$ & $-10 \pm 13$ \\
\hline & 1993 method & $-17 \pm 33^{c}$ & $-19 \pm 25$ \\
\hline \multirow[t]{2}{*}{ Lower soil $(20-135 \mathrm{~cm})$} & Fixed-mass (Figure 2) & $98 \pm 11$ & $73 \pm 9$ \\
\hline & 1993 method $^{d}$ & $0 \pm$ na & $0 \pm$ na \\
\hline$\Delta \mathrm{N}_{\text {soil }}$ total & Fixed-mass & $70 \pm 21$ & $63 \pm 16$ \\
\hline$\Delta \mathrm{N}_{\text {soil }}$ total & 1993 method & $-17 \pm 33$ & $-19 \pm 25$ \\
\hline $\mathrm{N}_{\mathrm{dr}}-\mathrm{N}_{\mathrm{bp}}$ (output-input) & 1993 methods $^{d}$ & $-4 \pm$ na & $-4 \pm$ na \\
\hline \multicolumn{4}{|l|}{$\begin{array}{l}\text { Alternative estimates of } \\
\text { ecosystem unexplained } \mathrm{N}^{e}\end{array}$} \\
\hline Minimum rate & $\begin{array}{l}\mathrm{N} \text {-height regression, most } \\
\text { negative upper- and no lower- } \\
\text { soil } \mathrm{N} \text { changes }\end{array}$ & $42 \pm 29$ & $42 \pm 26$ \\
\hline Reported rate & 1993 methods & $62 \pm 34$ & $49 \pm 47$ \\
\hline Maximum rate & $\begin{array}{l}1993 \Delta \mathrm{N}_{\mathrm{veg}} \text { fixed-mass upper } \\
\text { and lower soil }\end{array}$ & $149 \pm 23$ & $130 \pm 43$ \\
\hline \multicolumn{4}{|c|}{ 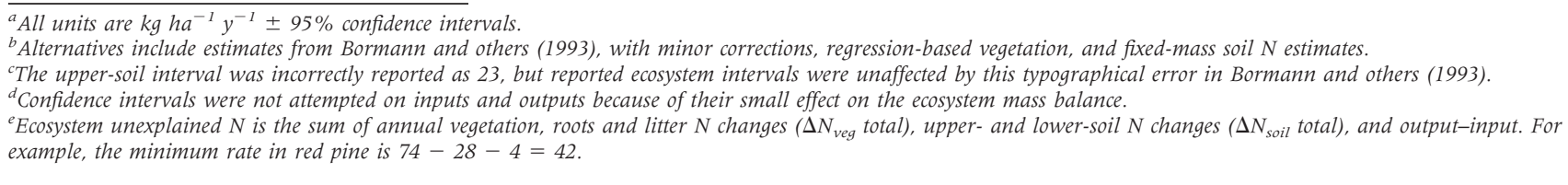 } \\
\hline
\end{tabular}

Estimates of unexplained ecosystem $\mathrm{N}$ change (Table 3) ranged from $42 \mathrm{~kg} \mathrm{ha}^{-1} \mathrm{y}^{-1}$ (based on the aboveground $\mathrm{N}$ estimate from the regression method and assuming no $\mathrm{N}$ change in lower soil) to 130-149 $\mathrm{kg} \mathrm{ha}^{-1} \mathrm{y}^{-1}$ (based on including aboveground vegetation $\mathrm{N}$ means and lower-soil $\mathrm{N}$ change estimates). Viewed slightly differently, the aboveground accumulation of $\mathrm{N}$ in pine vegetation could be explained by the loss of $\mathrm{N}$ in lower soil (as suggested by Binkley and others 2000) only if such $\mathrm{N}$ losses were considered so large as to be inconsistent with what we know about initial conditions (Figure 2). We believe that the weight of evidence cannot support such interpretive choices. We cannot avoid the conclusion that unexplained $\mathrm{N}$ has accumulated at modest to large rates in these sandboxes.

\section{Discussion}

A major advance in the understanding of the $\mathrm{N}$ cycle may well be imminent, but confidence in the conclusion that $\mathrm{N}$ accumulates rapidly without symbiotic $\mathrm{N}_{2}$-fixing plants at ecologically important scales of time and space will not be achieved easily. Mesocosm studies will likely play a critical role in this discovery because they can speed the detection of changes in soils and account for other important processes. However, to acknowledge a point raised implicitly by Binkley and others (2000): Mesocosm experiments are a challenging undertaking that requires large commitments of resources to achieve the experimental control and measurement accuracy needed to detect changes over a few years. Our finding of significant and large changes in lowersoil horizons in the sandboxes should also raise concerns about studies that fail to quantify deep soil changes, as difficult as that is.

In addition to controlling errors and bias better, future studies aimed at quantifying the potential for high rates of unexplained $\mathrm{N}$ accumulations more accurately are likely to be more successful if they focus on plants, soils, and climates that have already been implicated, such as red and pitch pine on unweathered glacial soils. Given the evidence supporting unexplained $\mathrm{N}$ in a few well-documented cases, the time is ripe to invest in studies that can help us to understand how this unex- 
plained $\mathrm{N}$ is accumulating. Future studies should attempt to directly quantify ecosystem $\mathrm{N}_{2}$ fixation rates with multiple approaches, including more field ${ }^{15} \mathrm{~N}$ studies. Microbiological studies, such as those already underway in tropical grasses (James and Olivares 1997; James 2000), are also needed to look for $\mathrm{N}_{2}$-fixing bacteria in soils, rhizospheres, and inside the roots of temperate zone pines and other species adapted to low- $\mathrm{N}$ environments.

\section{ACKNOWLEDGMENTS}

This research was supported by the USDA Forest Service, Pacific Northwest Research Station, longterm ecosystem productivity program, an A.W. Mellon Foundation grant to F.H.B., and a National Science Foundation grant (EAR-96-28296) to C.K.K. We thank Patrick Cunningham for advice on statistical interpretations, Gary Hawley for technical assistance, and Martha Brookes for editorial guidance.

\section{REFERENCES}

App A, Watanabe I, Alexander M, Ventura W, Daez C, Santiago T, De Datta SK. 1980. Non-symbiotic nitrogen fixation associated with the rice plant in flooded soils. Soil Sci 130:283-9.

Binkley D, Son Y, Valentine DW. 2000. Do forests receive occult inputs of nitrogen? Ecosystems 3:321-31.

Bormann BT, Bormann FH, Bowden WB, Pierce RS, Hamburg SP, Wang D, Snyder MC, Li CY, Ingersoll RC. 1993. Rapid $\mathrm{N}_{2}$ fixation in pines, alder, and locust: evidence from the sandbox ecosystem study. Ecology 74:581-98.

Bormann FH, Bowden WB, Pierce RS, Hamburg SP, Voigt GK, Ingersoll RC, Likens GE. 1987. The Hubbard Brook sandbox experiment. In: Jordan WR, Gilpin ME, Aber JD, editors. Restoration ecology. Cambridge (UK): Cambridge University Press. p 251-6.

Cavalcante VA, Dobereiner J. 1988. A new acid-tolerant nitrogen-fixing bacterium associated with sugarcane. Plant Soil 108:23-31.

Chapman HD, Liebig GE, Rayner DS. 1949. A lysimeter investigation of nitrogen gains and losses under various systems of covercropping and fertilization, and a discussion of error sources. Hilgardia 19:57-128.
Cochran WG. 1977. Sampling techniques. New York: Wiley. 428 p.

Day JM, Harris D, Dart PJ, Van Berkum P. 1975. The Broadbalk experiment: an investigation of nitrogen gains from nonsymbiotic nitrogen fixation. In: Stewart WDP, editor. Nitrogen fixation by free-living micro-organisms. Cambridge (UK): Cambridge University Press. p 71-84.

Dickson BA, Crocker RL. 1953. A chronosequence of soils and vegetation near Mt. Shasta, California. J Soil Sci 4:142-54.

Eriksson HM, Rosen K. 1994. Nutrient distribution in a Swedish tree species experiment. Plant Soil 164:51-9.

Fisher RF, Eastburn RP. 1974. Afforestation alters prairie soil nitrogen status. Soil Sci Soc Am Proc 38:366-8.

James EK. 2000. Nitrogen fixation in endophytic and associative symbiosis. Field Crops Res 65:197-209.

James EK, Olivares FL. 1997. Infection and colonization of sugar cane and other graminaceous plants by endophytic diazotrophs. Crit Rev Plant Sci 17:77-119.

Jenny H. 1980. The soil resource: origin and behavior. New York: Springer-Verlag. 377 p.

Johnson DW, Todd DE. 1998. Harvesting effects on long-term changes in nutrient pools of mixed oak forest. Soil Sci Soc Am J 62:1725-35.

Karraker PE, Bortner CE, Fergus EN. 1950. N balance in lysimeters as affected by growing Kentucky bluegrass and certain legumes separately and together. Ky Agric Exp Stat Bull 557: $1-16$.

Lima E, Boddey RM, Dobereiner J. 1987. Quantification of biological nitrogen fixation associated with sugar cane using a ${ }^{15} \mathrm{~N}$ aided nitrogen balance. Soil Biol Biochem 19:165-70.

Meyer SL. 1975. Data analysis for scientists and engineers. New York: Wiley. 513 p.

Smith RM, Thompson DO, Collier JW, Hervey RJ. 1954. Soil organic matter, crop yields, and land use in the Texas blackland. Soil Sci 77:377-88.

Son Y, Gower ST. 1992. Nitrogen and phosphorus distribution for five plantation species in southwestern Wisconsin. For Ecol Manage 53:175-93.

Turvey ND, Smethurst PJ. 1988. Apparent accumulation of nitrogen in soil under radiata pine: misleading results from a chronosequence. In: Dyck WJ, Mees CA, editors. Research strategies for long-term site productivity. IEA/BE Report 8. Rotorua (NZ): New Zealand Forest Research Institute. p 3943.

Whitt DM. 1941. The role of bluegrass in the conservation of the soil and its fertility. Soil Sci Soc Am Proc 6:309-11. 